\title{
Analysis of Energy Produced and Distributed in Rigid Pavement
}

\author{
Abhilekh Srivastava ${ }^{1}$, D. S Ray ${ }^{2}$ \\ ${ }^{1}$ M. Tech Scholar, Department of Civil Engineering, BBDU, Lucknow, India \\ ${ }^{2}$ Professor and Head of Department, Department of Civil Engineering, BBDNITM, Lucknow, India
}

\begin{abstract}
Modern time requires higher speed and lesser time of travel between origin and destination hence expressways, of rigid pavement have attained more priority than other category of pavement. They have a design module of lesser intersections, lesser obstruction hence providing higher speeds even $>100 \mathrm{kmph}$. This paper has analysed the amount of energy that is contributed by the higher texture depths into the rolling tires. This paper tries to study the energy produced when the tire rolls on the surface of rigid pavement and how it gets distributed into the atmosphere and absorbed by the rubber. For the analysis, pressure and temperature of the tire had a key role in the calculation of the energy produced. The concept of kinetic theory of gases helped us in idealising the nature of the movement of gas molecules and in calculating the energy transfer to the gas molecules. The increase in the kinetic energy gave us the conclusion about the mean texture depth that can be adopted in the designing of the rigid pavement. At different ages of the tire, the relationship between change in kinetic energy and the age of tire has been summarised. For the test site it was concluded that texture depth $>2.75 \mathbf{m m}$ is not suitable and greater than this will lead to tire burst accidents.
\end{abstract}

Keywords:- Rigid pavement, expressway, tire, tire burst, energy, energy transfer, kinetic energy

\section{INTRODUCTION}

In the modern world, Transportation has reached to a new level with enhanced technology and different material for its construction. The rigid pavement design (expressways) has given higher speed but has somehow compromised in the surface friction part too and to balance this part there has been a provision of higher texture depths which has given better griping value both in dry and wet conditions. This paper tries to make study of the energy produced when a tire rolls on the surface of rigid pavement and how it gets distributed into the atmosphere and some absorbed by the rolling tire. This paper gives emphasis on the portion of energy produced because of the texture provided on the pavement; and does not include the loss of energy due to any other cause. Necessary assumption has been made to absorb the other cause of energy dissipation. Texture provided on the pavement is basically a series of repeating figures drawn transverse to the moving direction in order to attain a desired value of skid resistance and friction so as to avoid skidding in any condition. But in view of this there is an abrupt increase in the amount of energy being produced and this is causing the problem of tire bursting.

Since the approach to this research is more or less based on the theoretical approach but still some efforts has been made to give the practical relation in the research work and for this purpose the first thing that is being calculated is the inflation pressure inside the tyre and using certain formulas and certain theoretical relations related to the energy, conclusion is being made about the work done but with lots left for the coming research which is to be done in this respect. Inflation pressure of the tyre is one of basic aspect that can be calculated with utmost precision. The selection of site is also done on the requirement basis and since rigid pavement expressway was needed, therefore Yamuna Expressway connecting Greater Noida with Agra was selected. Yamuna expressway has witnessed many accidents in the past years and tire bursting has been found one of the reasons of accident. It has been seen that the texture depth of the pavement is high enough in causing tire burst hence making it necessary to study this phenomenon and suggest a suitable depth which provided will help in reducing such accidents.

\subsection{GAY LUSSAC'S LAW}

The first major concept used in our analysis is Gay-lussac's law which relates the pressure with the absolute temperature of a given mass of gas. When there is a rigid container filled with a gas and its temperature is increased then the pressure of the gas increases and this results in increase in the kinetic energy ass the molecules of the gas starts striking the wall of the container with a greater force. Therefore Joseph GayLussac proposed a law named Gay-Lussac's Law which states that the pressure of a given mass of gas varies directly with the absolute temperature of the gas when the volume is kept constant. This concept is valid for ideal gases. The mathematical expression for the law is as follows:

$$
\frac{P_{1}}{T_{1}}=\frac{P_{2}}{T_{2}}
$$

\subsection{KINETIC THEORY OF GASES}

Since the analysis is involving the study of ideal gas therefore the kinetic theory of gases concept comes into the picture. Kinetic theory of gases is based on the molecular level of the matter. A gas is basically a collection of large number of molecules (in the order of Avogadro's number) that are in constant random motion in which at ordinary pressure and temperature the intermolecular distance between the molecules is in the factor of $10 \AA$ or more than the typical size of a molecule. Thus it is assumed that the molecules move freely in straight lines according to Newton's first Law but that's not the case. These molecules come close to each other and strike each other called as "collisions" and this collision changes their velocity.

In this theory it is considered that these collisions either with each other or with the walls are elastic meaning that the total kinetic energy and the total momentum is conserved and the velocity after the collision does not change.

Pressure exerted on the wall, $\mathrm{P}=(1 / 3) \mathrm{nm} \sum v^{2}$ 


\subsection{KINETIC INTERPRETATION OF TEMPERATURE}

We know that

$\mathrm{PV}=(1 / 3) \mathrm{nVm} \sum v^{2}$

$\mathrm{PV}=(2 / 3) \mathrm{N} \sum v^{2}$ where $\mathrm{N}$ is the number of molecules in the gas sample

This quantity is the average translational kinetic energy of the molecules in the gas and hence $\mathrm{E}=(1 / 3) \mathrm{nVm} \sum v^{2}$

Therefore the final equation of the interpretation of temperature is as:

$\mathrm{E}=(3 / 2) \mathrm{k}_{\mathrm{b}} \mathrm{NT}$ or $=(3 / 2) \mathrm{k}_{\mathrm{b}} \mathrm{T}$

i.e the average kinetic energy of a molecule is proportional to the absolute temperature of the gas and is independent of pressure, volume or the nature of gas. The two parameters are connected by the Boltzmann constant, $\mathrm{k}_{\mathrm{b}}$. With this relation the kinetic energy of an ideal gas is consistent with the ideal gas equation and other gas laws equation.

\subsection{LAW OF EQUIPARTITION OF ENERGY}

As here in our study, the work is going on for a diatomic gas like $\mathrm{O}_{2}, \mathrm{~N}_{2}$ etc. hence the translational degree of freedom for the diatomic gas is three and it also spins about its centre of mass about two axes so therefore the total degree of freedom for a diatomic gas is five. In thermal equilibrium at absolute temperature it is seen that each translational mode of motion has an energy equal to $(1 / 2) \mathrm{k}_{\mathrm{B}} \mathrm{T}$. Hence the average kinetic energy for a monoatomic gas having three degree of freedom will be $(3 / 2) \mathrm{k}_{\mathrm{b}} \mathrm{T}$ and similarly for a diatomic gas it will be $(5 / 2) \mathrm{k}_{\mathrm{b}} \mathrm{T}$ since it has three translational motion and two rotational motion.

\section{LITERATURE REVIEW}

Afzali B (2006) ${ }^{12}$ This paper studied the effect of change in one step of production of tire on the thermal properties and temperature distribution of the rolling tire by performing a finite element modelling of heat transfer and temperature distribution of a steady state rolling tire. It provided the critical points and the maximum temperature in a rolling tire and it helps in choosing best structure and material of the tire.

L.Tighe (2008) ${ }^{1}$ This paper performed its study to determine the optimum surface friction and the mean texture depth for cement concrete surface and it was found that mean texture depth of about $1.8 \mathrm{~mm}$ provided the maximum friction on textured PCC surface. The different combinations of textures used in preparing the specimen are screed finish, burlap, corn broom and plastic turf drag, exposed aggregate. Woodside (2011) ${ }^{13}$ This paper has done laboratory tests to measure the dynamic vertical, transverse and longitudinal contact forces under tires with varying inflation pressure and loads. It gave a point that longitudinal contact stresses at the trailing edge of the contact patch were on the higher side when the inflation pressure was low.

Yuanmang Xia (2012) ${ }^{6}$ This paper has developed a new wireless temperature measurement system that aims to measure the interior temperature distribution of the rolling tire. It gave a vital point with respect to the temperature distribution in a rolling tire that at the beginning the tire temperature is in equilibrium with the ambient air temperature and starts absorbing energy and there is an increase in temperature and after much time it attains an equilibrium or steady state when all the heat generated is transferred to the ambient air and road through the tire boundary.

Zuraulis (2014) ${ }^{14}$ This paper made an analysis of the impact of the road micro profile on the duration and the type tire road contact with the pavement moving at different speed. It provided a precise data on different types of irregularities relation with the contact time of moving tire with the surface. Sadok Sassi (2015) ${ }^{\mathbf{1 0}}$ This paper gave a model analysis of the vehicle whose one tire is burst and provided result on the stability and geometry of the vehicle and the driver when phenomenon of tire burst occur. Since tire burst is a fatal phenomenon it relates all the changes that occur in a moving vehicle when the tire blows out.

Grinchuk(2016) ${ }^{\mathbf{8}}$ This paper made a study on the heat exchange with air and gave the temperature profile of moving oversize tire. It gave the mathematical model of heat transfer in a tire and its heat exchange with air. The mean temperature profiles were calculated by considering transition to a stationary thermal regime and the influence of the rate of energy dissipation and of effective thermal conductivity of rubber on the temperature field is investigated.

\section{DATA COLLECTION}

Yamuna expressway also known as Taj Expressway is basically a 6 lane, extendable to 8 lanes, $165 \mathrm{~km}$ long access controlled expressway which connects Greater Noida with Agra in the territory of Uttar Pradesh. It is one of the India's longest six lane expressway. This expressway starts from Pari Chowk in Greater Noida and ends at Kuberpur in Agra. It is monitored and maintained by a body called Yamuna Expressway Industrial Development Authority (YEIDA).

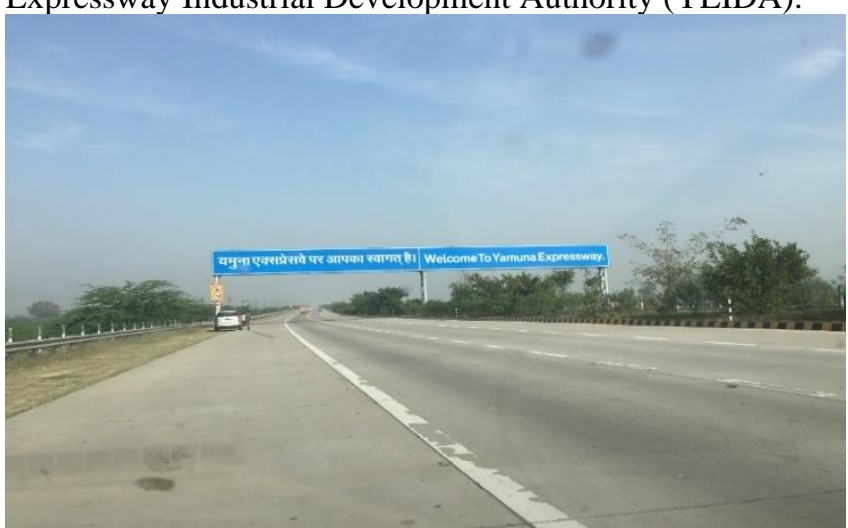

Fig. 1 View of Yamuna Expressway

The accident data of the Yamuna Expressway, of the past three years, was made available to us. There was not much classification of the accidents by which cause they have occurred but tyre bursting was one of the many causes due to which those accidents have occurred. The number of road accidents have been on the decrement side but the number of fatal casualties increased. 


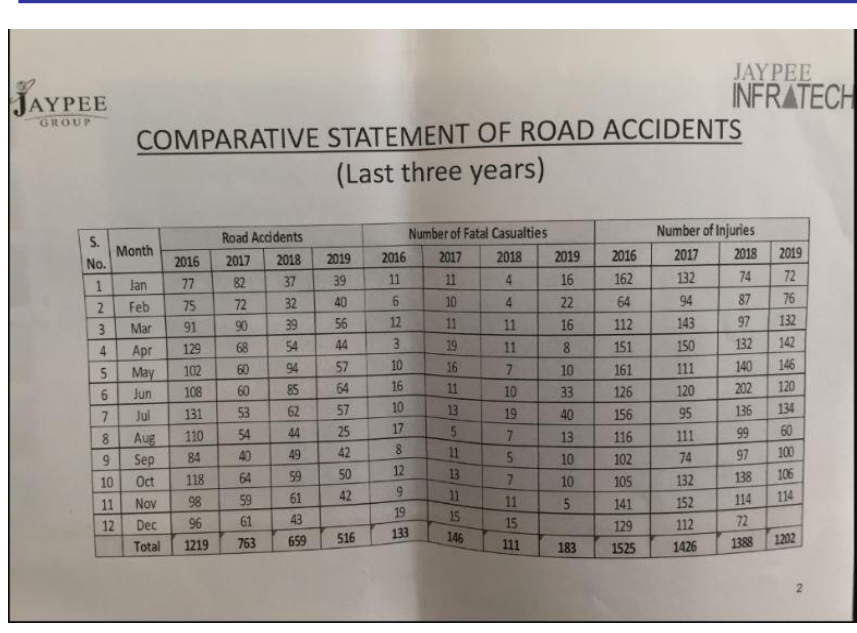

Fig. 2 Accident Data of Yamuna Expressway

With due permission from the concerned authority some basic technical features of the expressway were obtained.

\begin{tabular}{|c|c|c|}
\hline S.NO. & DESCRIPTION & \\
\hline 1. & Total number of lanes & $6: 3.5 \mathrm{~m}$ width each \\
\hline 2. & Permissible speed & $\begin{array}{l}100 \mathrm{kmph} \text { for LMV } \\
60 \mathrm{kmph} \text { for HMV }\end{array}$ \\
\hline 3. & Maximum Allowable speed & $120 \mathrm{kmph}$ \\
\hline 4. & Total length & $165.5 \mathrm{~km}$ \\
\hline 5. & Right of Way & $100 \mathrm{~m}$ wide \\
\hline 6. & Pavement Width & $15.70 \mathrm{~m}$ \\
\hline 7. & Maximum axle load design & 20 tonnes \\
\hline 8. & Shoulder Width & $5.10 \mathrm{~m}$ \\
\hline 9. & Thickness of PQC & $\begin{array}{lr}320 & \mathrm{~mm}\end{array} \quad$ (main \\
\hline 10. & Thickness of DLC & $150 \mathrm{~mm}$ \\
\hline 11. & Top Width of Embankment & $\begin{array}{l}47.60 \mathrm{~m} \text { (including } 6.0 \\
\mathrm{~m} \text { wide Median) }\end{array}$ \\
\hline 12. & Vehicle underpass & 70 \\
\hline 13. & Minor bridges & 41 \\
\hline 14. & Interchanges & 6 \\
\hline 15. & Box Culverts & 182 \\
\hline 16. & Main Toll Plaza & $\begin{array}{l}3 \text { ( } 26 \text { lanes at each } \\
\text { location) }\end{array}$ \\
\hline 17. & Concrete & 33.2 lakh cum \\
\hline 18. & Cement & 12.0 lakh tonnes \\
\hline 19. & Steel & 1.30 lakh tonnes \\
\hline 20. & Stone Aggregate & 130 lakh tonnes \\
\hline 21. & Bitumen & 7500 tonnes \\
\hline 22. & Admixtures & 12500 tonnes \\
\hline
\end{tabular}

Table 1 Features of Yamuna Expressway

In March, the first trial of the experiment was conducted from the region Etmadpur to Gautam Budhh nagar by taking two vehicles of the same class; one in the morning and the other in the afternoon. There were no stops made in between the journey and constant average speed of about $90 \mathrm{kmph}$ was made. It was ensured that the tires used in this test are new and not worn out from before. Of the concerned moving vehicles the initial pressure readings of both the front and rear side (right and left both) tires were recorded with utmost accuracy that could be made on the road. The picture of the existing texture on the pavement was clicked and is shown below. In both the vehicles it was ensured that the pressure in the tires is maintained at the level as prescribed in the manual.

On completing the total length of the expressway then again the pressure of the tires is being recorded with all the precision and is noted in the sheet shown above. After analysing the sheet we could observe an increase in the pressure reading by about 2 psi in all the four tires of both the vehicles when the vehicle is loaded with the load of two persons of around $75 \mathrm{~kg}$.

\section{SHEETNO.1}

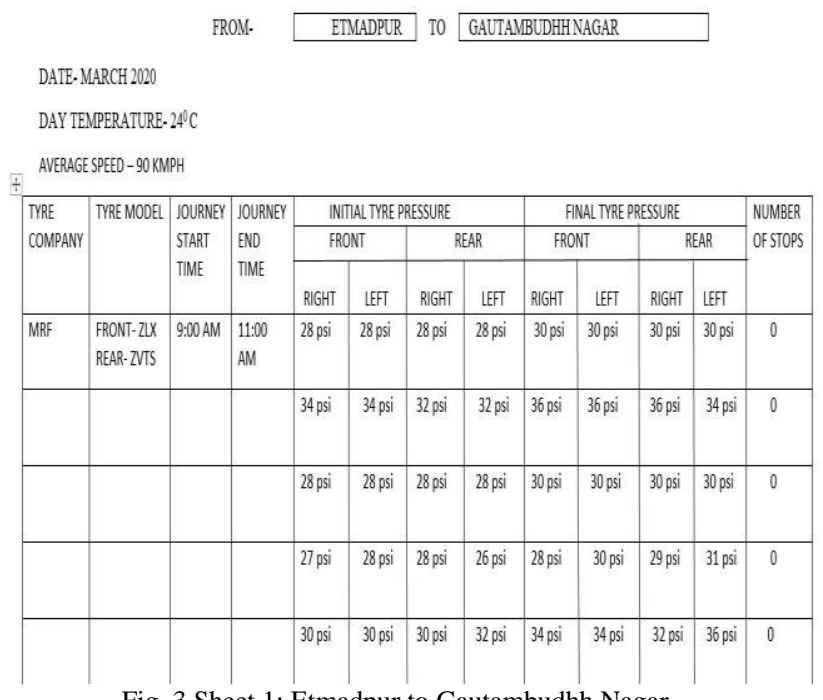

Fig. 3 Sheet 1: Etmadpur to Gautambudhh Nagar

Another trial was made on the next day but this time peak temperature was chosen so as to have the effect of high temperature on the test results also. This time the journey was made from the Gautam Budhh Nagar area to Etmadpur region. The loading conditions was kept the same and again the travel speed was maintained at $90 \mathrm{kmph}$. The concerned initial pressure reading was again taken with utmost precision. There was no stop in between the journey and the journey was completed in about the same time that was taken in the first test trial.

SHEETNO.2

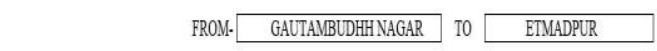

DATE-MARCH 2020

DAY TEMPERATURE- $32^{\circ} \mathrm{C}$

AVERAGE SPEED-90 KMPH

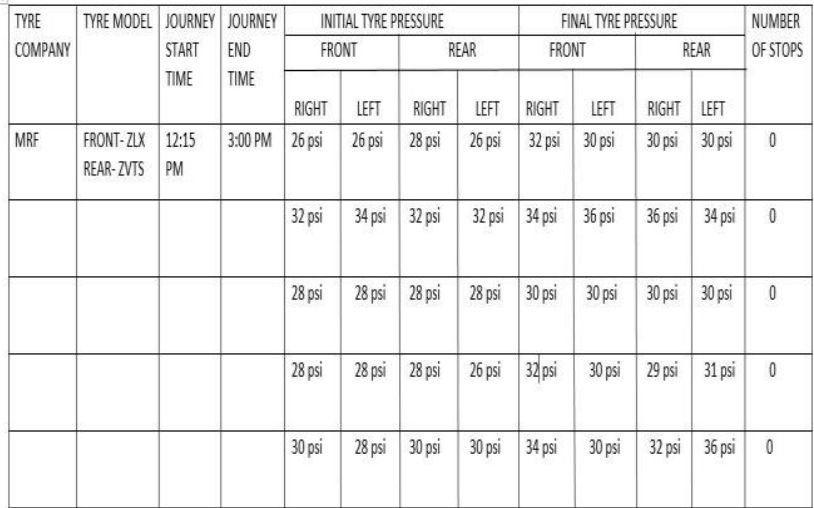

Fig. 4 Sheet 2: Gautambudhh Nagar to Etmadpur

From the above trial test we observed a significant increase in the pressure of the tires. The pressure in the front side tyres of the vehicle were kept 2 psi less than that of the 
prescribed value in the manual and those tires showed an increase of about 5-6 psi pressure value while the rear side tires which were filled with designated pressure value showed an increase of about 2-4 psi.

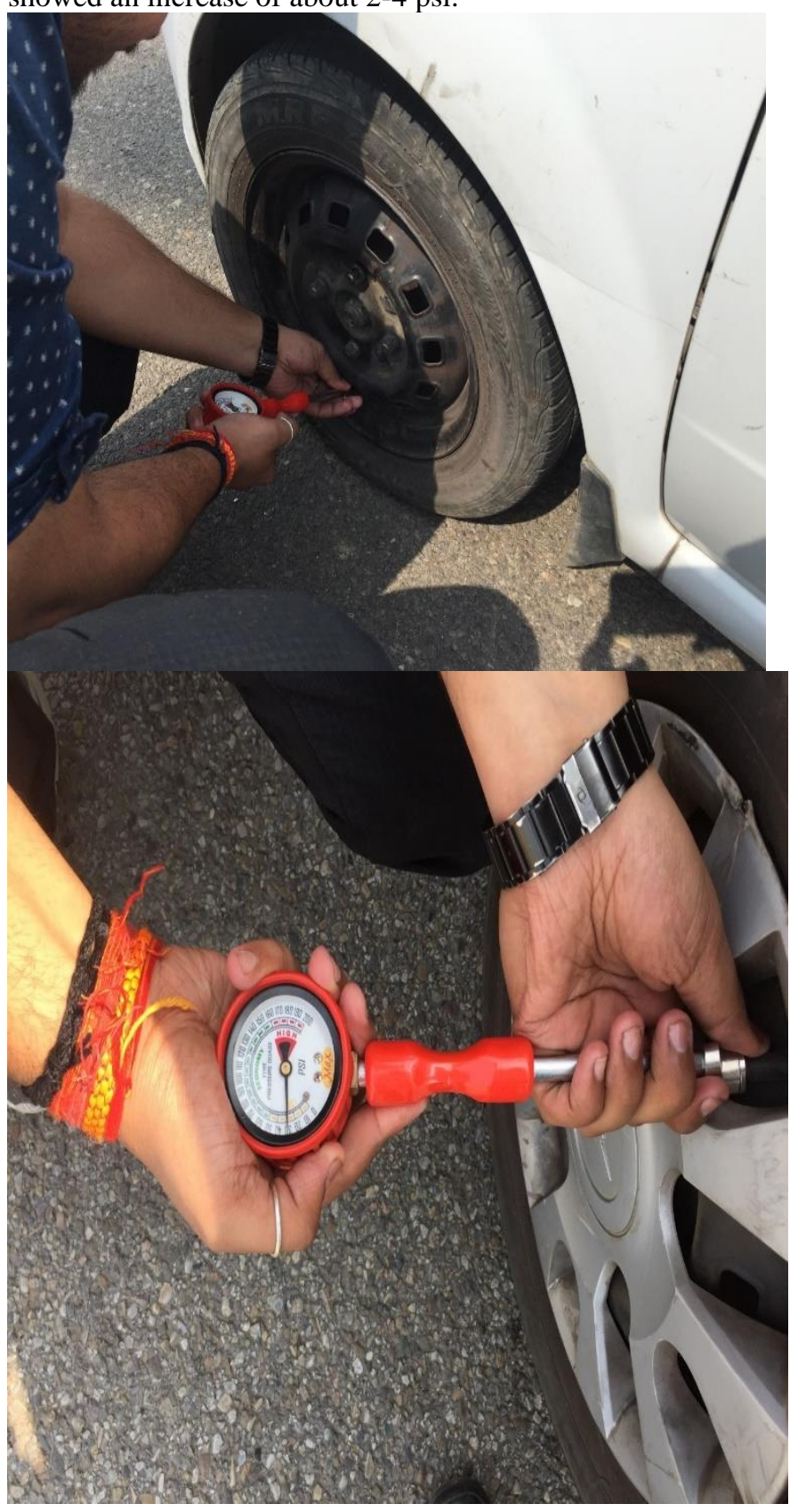

Fig. 5 Collection of Data

\section{DATA ANALYSIS}

After the collection of data, the calculation of the energy and other various aspects were calculated based on the perspective of the gas filled inside the tire and not from the perspective of the tire road contact since it required high and advanced technology for the calculation. Assumptions have been taken of the various laws and concept that are used for the calculation purpose. The one major assumption that has been taken is that the gas filled inside the tire is behaving as an ideal gas and undergoes perfectly elastic collision.
From the above collected data of the initial and final pressure, average three values were selected and the final temperature were calculated using Gay Lussac's Law. The standard initial temperature was taken to be $24^{\circ} \mathrm{C}$. The change in kinetic energy was calculated and is tabulated below.

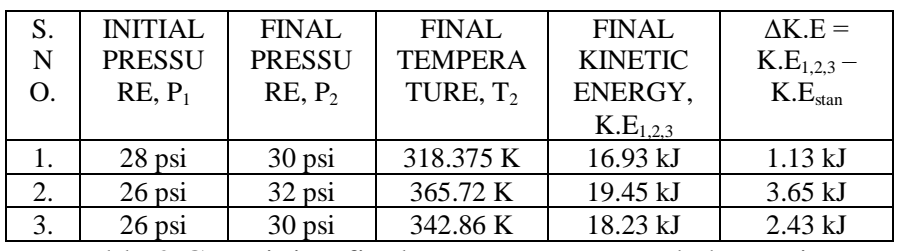

Table 2 Containing final temperature $\mathrm{T}_{2}$ and change in Kinetic Energy $\Delta$ K.E

Every tire has its maximum pressure that it can withstand based on its manufacturing and constituent materials and it decreases with the years and the kms it rolls on the pavement surface. Hence it becomes a major part in the provision of design of the rigid pavement since friction remaining constant in every situation, the capacity of the rolling tires will get reduced with increase in age and this deterioration level will prove fatal for the vehicle. Based on the data collected we can summarise the different situations of the tire at subsequent 1 year of interval and its decrease in the holding maximum pressure.

Case I: when the maximum pressure $=50 \mathrm{psi}=3.4 \mathrm{~atm}$ and initial pressure $=28 \mathrm{psi}=1.904 \mathrm{~atm}$

For $\mathrm{t}=0$ it means that the tire is new and can sustain maximum 50 psi pressure; for this condition the kinetic energy of the gas is calculated and at 1 year interval for different pressure conditions kinetic energies are calculated.

\begin{tabular}{|c|c|c|c|c|c|c|c|}
\hline $\begin{array}{l}\text { Age } \\
\text { of } \\
\text { tire, } \mathrm{t} \\
\text { (in } \\
\text { years } \\
\text { ) }\end{array}$ & $\begin{array}{c}\mathrm{P}_{1} \\
\text { (in } \\
\text { atm) }\end{array}$ & $\begin{array}{c}\mathrm{T}_{1} \text { (in } \\
\mathrm{K})\end{array}$ & $\begin{array}{c}\mathrm{P}_{2} \text { ( in } \\
\text { atm) (in } \\
\text { psi) }\end{array}$ & $\begin{array}{c}\mathrm{T}_{2} \text { (in } \\
\mathrm{K})\end{array}$ & $\begin{array}{c}\text { K.E }_{1} \\
\text { (in } \\
\mathrm{kJ} \text { ) }\end{array}$ & $\begin{array}{c}\mathrm{K} \mathrm{E}_{2} \\
\text { (in } \\
\mathrm{kJ} \text { ) }\end{array}$ & $\begin{array}{c}\Delta \mathrm{K} . \mathrm{E} \\
= \\
\mathrm{K} . \mathrm{E}_{2-} \\
\mathrm{K} . \mathrm{E}_{1}\end{array}$ \\
\hline 0 & $\begin{array}{l}1.90 \\
4\end{array}$ & $\begin{array}{l}297.1 \\
5\end{array}$ & $\begin{array}{l}3.40 \\
(50)\end{array}$ & $\begin{array}{l}530.62 \\
5\end{array}$ & $\begin{array}{l}15.8 \\
0\end{array}$ & $\begin{array}{l}28.2 \\
2\end{array}$ & 12.42 \\
\hline 1 & $\begin{array}{l}1.90 \\
4\end{array}$ & $\begin{array}{l}297.1 \\
5\end{array}$ & $\begin{array}{l}3.264(4 \\
8)\end{array}$ & 509.40 & $\begin{array}{l}15.8 \\
0\end{array}$ & $\begin{array}{l}27.0 \\
9 \\
\end{array}$ & 11.29 \\
\hline 2 & $\begin{array}{l}1.90 \\
4\end{array}$ & $\begin{array}{l}297.1 \\
5\end{array}$ & $\begin{array}{l}3.128(4 \\
6)\end{array}$ & $\begin{array}{l}488.17 \\
5\end{array}$ & $\begin{array}{l}15.8 \\
0\end{array}$ & $\begin{array}{l}25.9 \\
6 \\
\end{array}$ & 10.16 \\
\hline 3 & $\begin{array}{l}1.90 \\
4 \\
\end{array}$ & $\begin{array}{l}297.1 \\
5 \\
\end{array}$ & $\begin{array}{l}2.992(4 \\
4)\end{array}$ & 466.95 & $\begin{array}{l}15.8 \\
0 \\
\end{array}$ & $\begin{array}{l}24.8 \\
3 \\
\end{array}$ & 9.03 \\
\hline 4 & $\begin{array}{l}1.90 \\
4\end{array}$ & $\begin{array}{l}297.1 \\
5\end{array}$ & $\begin{array}{l}2.856(4 \\
2)\end{array}$ & $\begin{array}{l}445.72 \\
5\end{array}$ & $\begin{array}{l}15.8 \\
0\end{array}$ & $\begin{array}{l}23.7 \\
0\end{array}$ & 7.90 \\
\hline 5 & $\begin{array}{l}1.90 \\
4 \\
\end{array}$ & $\begin{array}{l}297.1 \\
5 \\
\end{array}$ & $2.72(40)$ & 424.50 & $\begin{array}{l}15.8 \\
0 \\
\end{array}$ & $\begin{array}{l}22.5 \\
7 \\
\end{array}$ & 6.77 \\
\hline
\end{tabular}

Table 3 Increase in kinetic energy at different age of tires (maximum pressure $=50 \mathrm{psi}$ ) 


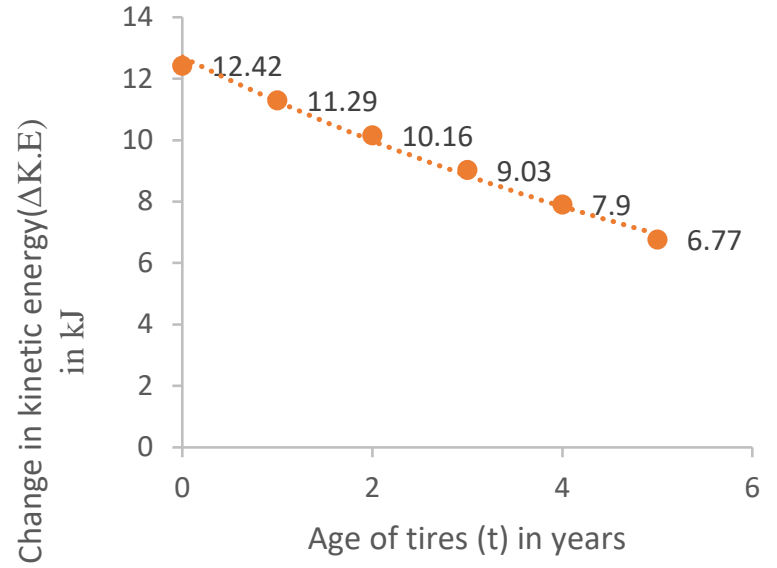

Fig. 6 Graph between age of tires and change in kinetic energy (maximum pressure $=50 \mathrm{psi}$ )

From the above graph it is estimated that with coming time the capacity of the tires to bear the kinetic energy decreases, not in a constant manner, and therefore if we limit the friction contribution in this energy we can come to the conclusion about the amount of texture that should be provided and of which particular depth.

Case II: when the initial pressure $=28 \mathrm{psi}$ and the maximum pressure $=51 \mathrm{psi}=3.468 \mathrm{~atm}$

\begin{tabular}{|c|c|c|c|c|c|c|c|}
\hline $\begin{array}{c}\text { Age } \\
\text { of } \\
\text { tire, } t \\
\text { (in } \\
\text { years } \\
\text { ) }\end{array}$ & $\begin{array}{c}\mathrm{P}_{1} \\
\text { (in } \\
\mathrm{atm} \text { ) }\end{array}$ & $\begin{array}{c}T_{1} \text { (in } \\
K \text { ) }\end{array}$ & $\begin{array}{l}\mathrm{P}_{2} \text { (in } \\
\mathrm{atm}) \text { (in } \\
\mathrm{psi} \text { ) }\end{array}$ & $\begin{array}{c}\mathrm{T}_{2} \text { (in } \\
\mathrm{K} \text { ) }\end{array}$ & $\begin{array}{l}\mathrm{K}_{\text {. }} \mathrm{E}_{1} \\
\text { (in } \\
\mathrm{kJ} \text { ) }\end{array}$ & $\begin{array}{c}\mathrm{K}_{\text {. }} \mathrm{E}_{2} \\
\text { (in } \\
\mathrm{kJ} \text { ) }\end{array}$ & $\begin{array}{c}\Delta \mathrm{K} . \mathrm{E} \\
= \\
\mathrm{K}^{\mathrm{E}} \mathrm{E}_{2} \\
\mathrm{~K} . \mathrm{E}_{1}\end{array}$ \\
\hline 0 & $\begin{array}{l}1.90 \\
4 \\
\end{array}$ & $\begin{array}{l}297.1 \\
5 \\
\end{array}$ & $\begin{array}{l}3.468(5 \\
1) \\
\end{array}$ & $\begin{array}{l}541.2 \\
3 \\
\end{array}$ & $\begin{array}{l}15.8 \\
0 \\
\end{array}$ & $\begin{array}{l}28.7 \\
8 \\
\end{array}$ & 12.98 \\
\hline 1 & $\begin{array}{l}1.90 \\
4 \\
\end{array}$ & $\begin{array}{l}297.1 \\
5 \\
\end{array}$ & $\begin{array}{l}3.332(4 \\
9)\end{array}$ & $\begin{array}{l}520.0 \\
1 \\
\end{array}$ & $\begin{array}{l}15.8 \\
0 \\
\end{array}$ & $\begin{array}{l}27.6 \\
5 \\
\end{array}$ & 11.85 \\
\hline 2 & $\begin{array}{l}1.90 \\
4 \\
\end{array}$ & $\begin{array}{l}297.1 \\
5 \\
\end{array}$ & $\begin{array}{l}3.196(4 \\
7)\end{array}$ & $\begin{array}{l}498.7 \\
8 \\
\end{array}$ & $\begin{array}{l}15.8 \\
0 \\
\end{array}$ & $\begin{array}{l}26.5 \\
2 \\
\end{array}$ & 10.72 \\
\hline 3 & $\begin{array}{l}1.90 \\
4 \\
\end{array}$ & $\begin{array}{l}297.1 \\
5 \\
\end{array}$ & $3.06(45)$ & $\begin{array}{l}477.5 \\
6 \\
\end{array}$ & $\begin{array}{l}15.8 \\
0 \\
\end{array}$ & $\begin{array}{l}25.3 \\
9 \\
\end{array}$ & 9.59 \\
\hline 4 & $\begin{array}{l}1.90 \\
4 \\
\end{array}$ & $\begin{array}{l}297.1 \\
5 \\
\end{array}$ & $\begin{array}{l}2.924(4 \\
3) \\
\end{array}$ & $\begin{array}{l}456.3 \\
3 \\
\end{array}$ & $\begin{array}{l}15.8 \\
0 \\
\end{array}$ & $\begin{array}{l}24.2 \\
7 \\
\end{array}$ & 8.47 \\
\hline 5 & $\begin{array}{l}1.90 \\
4\end{array}$ & $\begin{array}{l}297.1 \\
5 \\
\end{array}$ & $\begin{array}{l}2.788(4 \\
1)\end{array}$ & $\begin{array}{l}435.1 \\
1 \\
\end{array}$ & $\begin{array}{l}15.8 \\
0 \\
\end{array}$ & $\begin{array}{l}23.1 \\
4\end{array}$ & 7.34 \\
\hline
\end{tabular}

Table 4 Increase in kinetic energy at different age of tires (maximum pressure $=51 \mathrm{psi}$ )

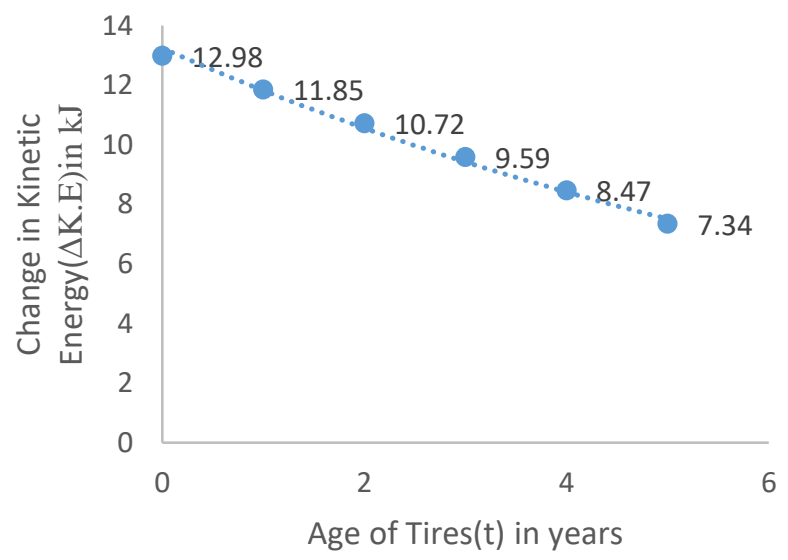

Fig. 7 Graph between age of tires and change in kinetic energy (maximum pressure $=51 \mathrm{psi}$ )
Case III: when the maximum pressure $=51 \mathrm{psi}$ and the initial pressure $=28$ psi. In this case we assume that the reduction in the maximum pressure is not constant.

\begin{tabular}{|c|c|c|c|c|c|c|c|}
\hline $\begin{array}{l}\text { Age } \\
\text { of } \\
\text { tire, } t \\
\text { (in } \\
\text { years } \\
\text { ) }\end{array}$ & $\begin{array}{c}\mathrm{P}_{1} \\
\text { (in } \\
\text { atm) }\end{array}$ & $\begin{array}{c}\mathrm{T}_{1} \text { (in } \\
\mathrm{K} \text { ) }\end{array}$ & $\begin{array}{c}\mathrm{P}_{2} \text { (in } \\
\text { atm) (in } \\
\text { psi) }\end{array}$ & $\begin{array}{c}\mathrm{T}_{2}(\mathrm{in} \\
\mathrm{K})\end{array}$ & $\begin{array}{r}\text { K.E } \\
\text { (in } \\
\mathrm{kJ} \text { ) }\end{array}$ & $\begin{array}{c}\text { K.E } E_{2} \\
\text { (in } \\
\text { kJ) }\end{array}$ & $\begin{array}{c}\Delta \mathrm{K} . \mathrm{E} \\
= \\
\mathrm{K} . \mathrm{E}_{2} \\
\mathrm{~K} . \mathrm{E}_{1}\end{array}$ \\
\hline 0 & $\begin{array}{l}1.90 \\
4\end{array}$ & $\begin{array}{l}297.1 \\
5 \\
\end{array}$ & $\begin{array}{l}3.468(5 \\
1)\end{array}$ & 541.23 & $\begin{array}{l}15.8 \\
0\end{array}$ & $\begin{array}{l}28.7 \\
8 \\
\end{array}$ & 12.98 \\
\hline 1 & $\begin{array}{l}1.90 \\
4 \\
\end{array}$ & $\begin{array}{l}297.1 \\
5 \\
\end{array}$ & $3.40(50)$ & $\begin{array}{l}530.62 \\
5 \\
\end{array}$ & $\begin{array}{l}15.8 \\
0 \\
\end{array}$ & $\begin{array}{l}28.2 \\
2 \\
\end{array}$ & 12.42 \\
\hline 2 & $\begin{array}{l}1.90 \\
4 \\
\end{array}$ & $\begin{array}{l}297.1 \\
5 \\
\end{array}$ & $\begin{array}{l}3.196(4 \\
7)\end{array}$ & 498.78 & $\begin{array}{l}15.8 \\
0 \\
\end{array}$ & $\begin{array}{l}26.5 \\
2 \\
\end{array}$ & 10.72 \\
\hline 3 & $\begin{array}{l}1.90 \\
4 \\
\end{array}$ & $\begin{array}{l}297.1 \\
5 \\
\end{array}$ & $\begin{array}{l}2.856(4 \\
2) \\
\end{array}$ & $\begin{array}{l}445.72 \\
5 \\
\end{array}$ & $\begin{array}{l}15.8 \\
0 \\
\end{array}$ & $\begin{array}{l}23.7 \\
0 \\
\end{array}$ & 7.90 \\
\hline 4 & $\begin{array}{l}1.90 \\
4 \\
\end{array}$ & $\begin{array}{l}297.1 \\
5 \\
\end{array}$ & $\begin{array}{l}2.856(4 \\
2) \\
\end{array}$ & $\begin{array}{l}445.72 \\
5 \\
\end{array}$ & $\begin{array}{l}15.8 \\
0 \\
\end{array}$ & $\begin{array}{l}23.7 \\
0 \\
\end{array}$ & 7.90 \\
\hline
\end{tabular}

Table 5 Increase in kinetic energy at different age of tires (maximum pressure $=51 \mathrm{psi}$ )

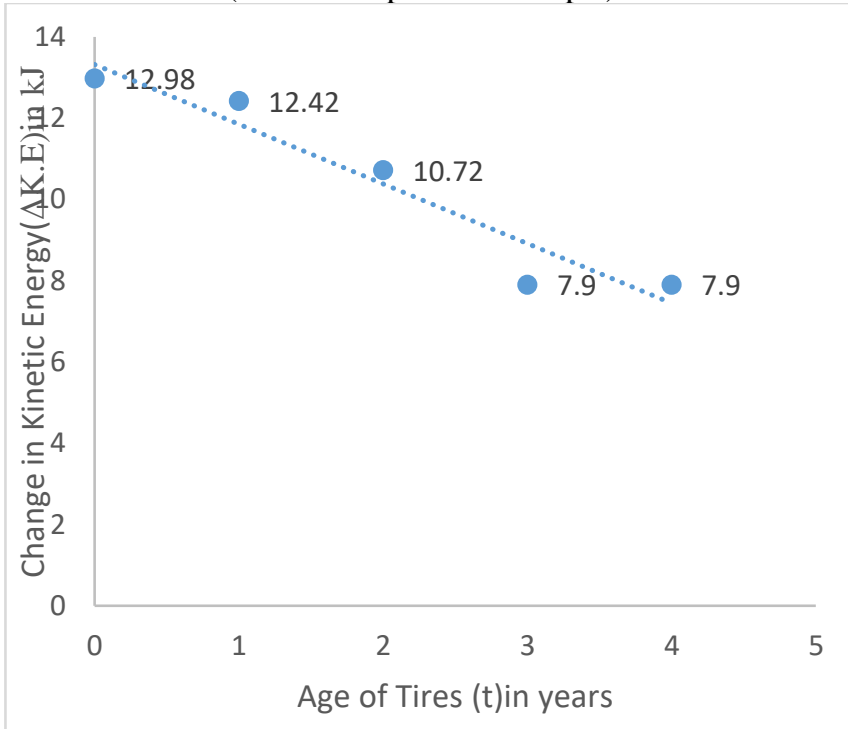

Fig. 8 Graph between age of tires and change in kinetic energy (maximum pressure $=51 \mathrm{psi}$ )

Case IV: when the normal pressure $=30 \mathrm{psi}$ and the maximum pressure of the tire $=44 \mathrm{psi}=2.992 \mathrm{~atm}$

\begin{tabular}{|c|c|c|c|c|c|c|c|}
\hline $\begin{array}{l}\text { Age } \\
\text { of } \\
\text { tire, } \\
\text { t (in } \\
\text { year } \\
\text { s) }\end{array}$ & $\begin{array}{l}P_{1} \text { (in } \\
\text { atm) }\end{array}$ & $\begin{array}{c}\mathrm{T}_{1} \text { (in } \\
\mathrm{K} \text { ) }\end{array}$ & $\begin{array}{c}\mathrm{P}_{2} \text { (in } \\
\text { atm) (in } \\
\text { psi) }\end{array}$ & $\begin{array}{c}\mathrm{T}_{2} \text { (in } \\
\mathrm{K})\end{array}$ & $\begin{array}{l}\text { K. } E_{1} \\
\text { (in } \\
\text { kJ) }\end{array}$ & $\begin{array}{l}\mathrm{K} . \mathrm{E}_{2} \\
\text { (in } \\
\mathrm{kJ} \text { ) }\end{array}$ & $\begin{array}{c}\Delta \mathrm{K} . \mathrm{E} \\
= \\
\mathrm{K} . \mathrm{E}_{2}- \\
\mathrm{K} . \mathrm{E}_{1}\end{array}$ \\
\hline 0 & $\begin{array}{l}2.04(3 \\
0)\end{array}$ & $\begin{array}{l}297.1 \\
5 \\
\end{array}$ & $\begin{array}{l}2.992(4 \\
4)\end{array}$ & $\begin{array}{l}335.8 \\
2 \\
\end{array}$ & $\begin{array}{l}15.8 \\
0 \\
\end{array}$ & $\begin{array}{l}23.1 \\
7 \\
\end{array}$ & 7.37 \\
\hline 1 & 2.04 & $\begin{array}{l}297.1 \\
5\end{array}$ & $\begin{array}{l}2.856(4 \\
2)\end{array}$ & $\begin{array}{l}416.0 \\
1\end{array}$ & $\begin{array}{l}15.8 \\
0 \\
\end{array}$ & $\begin{array}{l}22.1 \\
2 \\
\end{array}$ & 6.32 \\
\hline 2 & 2.04 & $\begin{array}{l}297.1 \\
5\end{array}$ & $\begin{array}{l}2.720(4 \\
0)\end{array}$ & $\begin{array}{l}396.2 \\
0\end{array}$ & $\begin{array}{l}15.8 \\
0\end{array}$ & $\begin{array}{l}21.0 \\
7\end{array}$ & 5.27 \\
\hline 3 & 2.04 & $\begin{array}{l}297.1 \\
5\end{array}$ & $\begin{array}{l}2.584(3 \\
8)\end{array}$ & $\begin{array}{l}376.3 \\
9\end{array}$ & $\begin{array}{l}15.8 \\
0\end{array}$ & $\begin{array}{l}20.0 \\
1\end{array}$ & 4.21 \\
\hline 4 & 2.04 & $\begin{array}{l}297.1 \\
5\end{array}$ & $\begin{array}{l}2.448(3 \\
6)\end{array}$ & $\begin{array}{l}356.5 \\
8\end{array}$ & $\begin{array}{l}15.8 \\
0\end{array}$ & $\begin{array}{l}18.5 \\
2\end{array}$ & 2.72 \\
\hline
\end{tabular}

Table 6 Increase in kinetic energy at different age of tires ( maximum pressure $=44 \mathrm{psi}$ ) 


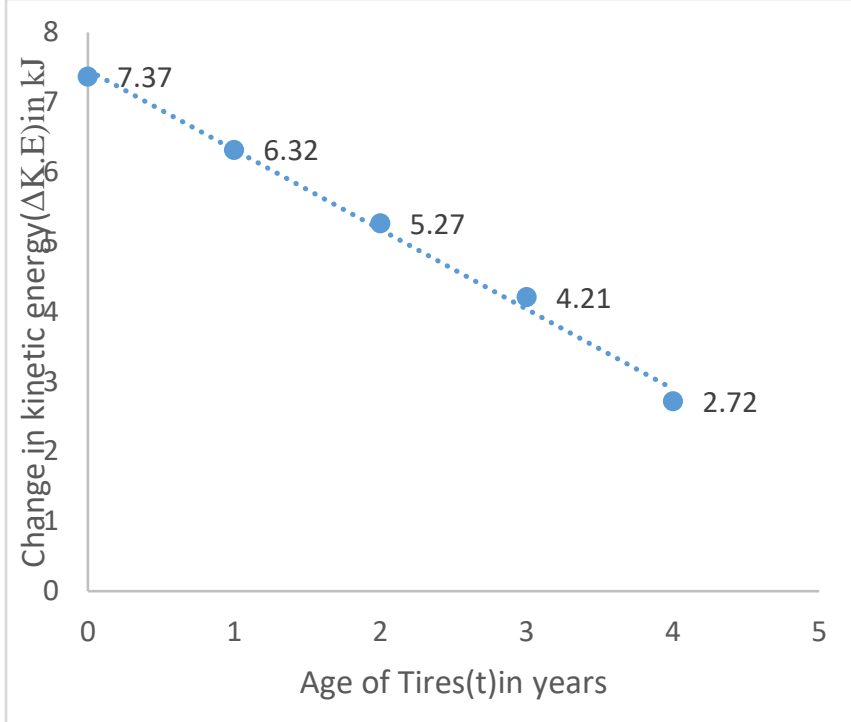

Fig. 9 Graph between age of tires and change in kinetic energy (maximum pressure $=44 \mathrm{psi}$ )

Case V: when the normal pressure $=30 \mathrm{psi}$ and the maximum pressure of the tire $=44 \mathrm{psi}=2.992 \mathrm{~atm}$

\begin{tabular}{|c|c|c|c|c|c|c|c|}
\hline $\begin{array}{l}\text { Age } \\
\text { of } \\
\text { tire, } t \\
\text { (in } \\
\text { years } \\
\text { ) }\end{array}$ & $\begin{array}{c}\mathrm{P}_{1} \\
\text { (in } \\
\text { atm } \\
\text { ) }\end{array}$ & $\begin{array}{l}\mathrm{T}_{1} \text { (in } \\
\mathrm{K} \text { ) }\end{array}$ & $\begin{array}{c}\mathrm{P}_{2} \text { (in } \\
\mathrm{atm} \text { ) (in } \\
\mathrm{psi} \text { ) }\end{array}$ & $\begin{array}{c}\mathrm{T}_{2} \text { (in } \\
\mathrm{K} \text { ) }\end{array}$ & $\begin{array}{l}\mathrm{K}_{\text {K.E }} \\
\text { (in } \\
\text { kJ) }\end{array}$ & $\begin{array}{c}\text { K.E } E_{2} \\
\text { (in } \\
\text { kJ) }\end{array}$ & $\begin{array}{c}\Delta \mathrm{K} . \mathrm{E} \\
= \\
\mathrm{K}^{-\mathrm{E}_{2}} \\
\text { K. } \mathrm{E}_{1}\end{array}$ \\
\hline 0 & $\begin{array}{l}2.0 \\
4\end{array}$ & $\begin{array}{l}297.1 \\
5\end{array}$ & $\begin{array}{l}2.992(4 \\
4)\end{array}$ & $\begin{array}{l}435.8 \\
2 \\
\end{array}$ & $\begin{array}{l}15.8 \\
0\end{array}$ & $\begin{array}{l}23.1 \\
7 \\
\end{array}$ & $\begin{array}{l}7.37 \\
\end{array}$ \\
\hline 1 & $\begin{array}{l}2.0 \\
4 \\
\end{array}$ & $\begin{array}{l}297.1 \\
5 \\
\end{array}$ & $\begin{array}{l}2.924(4 \\
3)\end{array}$ & $\begin{array}{l}425.9 \\
1\end{array}$ & $\begin{array}{l}15.8 \\
0\end{array}$ & $\begin{array}{l}22.6 \\
5\end{array}$ & 6.85 \\
\hline 2 & $\begin{array}{l}2.0 \\
4\end{array}$ & $\begin{array}{l}297.1 \\
5\end{array}$ & $\begin{array}{l}2.788(4 \\
1)\end{array}$ & $\begin{array}{l}406.1 \\
0\end{array}$ & $\begin{array}{l}15.8 \\
0\end{array}$ & $\begin{array}{l}21.5 \\
9\end{array}$ & 5.79 \\
\hline 3 & $\begin{array}{l}2.0 \\
4\end{array}$ & $\begin{array}{l}297.1 \\
5\end{array}$ & $\begin{array}{l}2.652(3 \\
9)\end{array}$ & $\begin{array}{l}386.2 \\
9\end{array}$ & $\begin{array}{l}15.8 \\
0\end{array}$ & $\begin{array}{l}20.5 \\
4\end{array}$ & 4.74 \\
\hline 4 & $\begin{array}{l}2.0 \\
4\end{array}$ & $\begin{array}{l}297.1 \\
5\end{array}$ & $\begin{array}{l}2.516(3 \\
7)\end{array}$ & $\begin{array}{l}366.4 \\
8\end{array}$ & $\begin{array}{l}15.8 \\
0\end{array}$ & $\begin{array}{l}19.4 \\
9\end{array}$ & 3.69 \\
\hline
\end{tabular}

Table 7 Increase in kinetic energy at different age of tires (maximum pressure $=44 \mathrm{psi}$ )

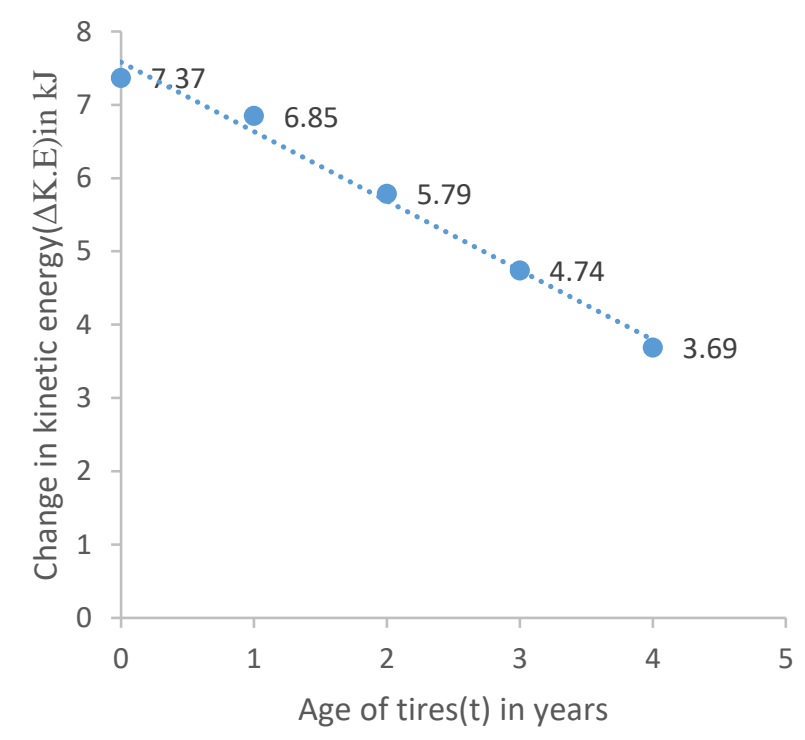

Fig. 10 Graph between age of tires and change in kinetic energy ( maximum pressure $=44 \mathrm{psi}$ )
Case VI: when the normal pressure $=30 \mathrm{psi}$ and the maximum pressure of the tire $=44 \mathrm{psi}$. In this case the deterioration is not taken as constant and accordingly graph is plotted.

\begin{tabular}{|c|c|c|c|c|c|c|c|}
\hline $\begin{array}{l}\text { Age } \\
\text { of } \\
\text { tire, } t \\
\text { (in } \\
\text { years } \\
\text { ) }\end{array}$ & $\begin{array}{c}\mathrm{P}_{1} \\
\text { (in } \\
\text { atm } \\
\text { ) }\end{array}$ & $\begin{array}{c}\mathrm{T}_{1} \text { (in } \\
\mathrm{K} \text { ) }\end{array}$ & $\begin{array}{c}\mathrm{P}_{2} \text { (in } \\
\mathrm{atm}) \text { (in } \\
\mathrm{psi} \text { ) }\end{array}$ & $\begin{array}{c}\mathrm{T}_{2} \text { (in } \\
\mathrm{K} \text { ) }\end{array}$ & $\begin{array}{l}\text { K.E } E_{1} \\
\text { (in } \\
\mathrm{kJ} \text { ) }\end{array}$ & $\begin{array}{c}\text { K.E } E_{2} \\
\text { (in } \\
\mathrm{kJ} \text { ) }\end{array}$ & $\begin{array}{c}\Delta \mathrm{K} . \mathrm{E} \\
= \\
\mathrm{K} . \mathrm{E}_{2} \\
\mathrm{~K} . \mathrm{E}_{1}\end{array}$ \\
\hline 0 & $\begin{array}{l}2.0 \\
4\end{array}$ & $\begin{array}{l}297.1 \\
5\end{array}$ & $\begin{array}{l}2.992(4 \\
4)\end{array}$ & $\begin{array}{l}435.8 \\
2\end{array}$ & $\begin{array}{l}15.8 \\
0\end{array}$ & $\begin{array}{l}23.1 \\
7\end{array}$ & 7.37 \\
\hline 1 & $\begin{array}{l}2.0 \\
4\end{array}$ & $\begin{array}{l}297.1 \\
5\end{array}$ & $\begin{array}{l}2.788(4 \\
1)\end{array}$ & $\begin{array}{l}406.1 \\
0\end{array}$ & $\begin{array}{l}15.8 \\
0\end{array}$ & $\begin{array}{l}21.5 \\
9\end{array}$ & 5.79 \\
\hline 2 & $\begin{array}{l}2.0 \\
4 \\
\end{array}$ & $\begin{array}{l}297.1 \\
5 \\
\end{array}$ & $\begin{array}{l}2.788(4 \\
1)\end{array}$ & $\begin{array}{l}406.1 \\
0 \\
\end{array}$ & $\begin{array}{l}15.8 \\
0 \\
\end{array}$ & $\begin{array}{l}21.5 \\
9 \\
\end{array}$ & 5.79 \\
\hline 3 & $\begin{array}{l}2.0 \\
4 \\
\end{array}$ & $\begin{array}{l}297.1 \\
5 \\
\end{array}$ & $2.72(40)$ & $\begin{array}{l}396.2 \\
0\end{array}$ & $\begin{array}{l}15.8 \\
0\end{array}$ & $\begin{array}{l}21.0 \\
7\end{array}$ & 5.27 \\
\hline 4 & $\begin{array}{l}2.0 \\
4\end{array}$ & $\begin{array}{l}297.1 \\
5\end{array}$ & $\begin{array}{l}2.516(3 \\
7)\end{array}$ & $\begin{array}{l}366.4 \\
8\end{array}$ & $\begin{array}{l}15.8 \\
0\end{array}$ & $\begin{array}{l}19.4 \\
9\end{array}$ & 3.69 \\
\hline
\end{tabular}

Table 8 Increase in kinetic energy at different age of tires (maximum pressure $=44 \mathrm{psi}$ )

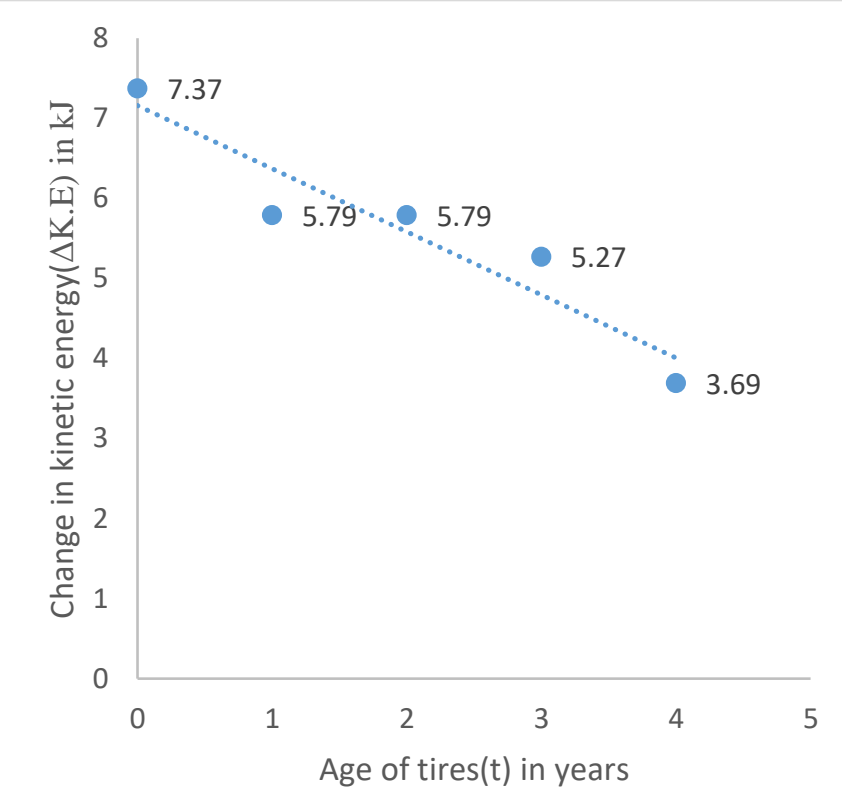

Fig. 11 Graph between age of tires and change in kinetic energy (maximum pressure $=44 \mathrm{psi}$ )

Case VII: when the normal pressure $=33$ psi and the maximum pressure of the tires $=61 \mathrm{psi}$

\begin{tabular}{|c|c|c|c|c|c|c|c|}
\hline $\begin{array}{l}\text { Age } \\
\text { of } \\
\text { tire, } \\
\mathrm{t} \text { (in } \\
\text { year } \\
\text { s) }\end{array}$ & $\begin{array}{l}P_{1} \text { (in } \\
\text { atm) }\end{array}$ & $\begin{array}{l}\mathrm{T}_{1} \\
\text { (in } \\
\mathrm{K} \text { ) }\end{array}$ & $\begin{array}{l}\mathrm{P}_{2} \text { (in } \\
\text { atm) (in } \\
\text { psi) }\end{array}$ & $\begin{array}{l}\mathrm{T}_{2} \\
\text { (in } \\
\mathrm{K})\end{array}$ & $\begin{array}{l}\text { K.E } \\
1 \text { (in } \\
\text { kJ) }\end{array}$ & $\begin{array}{l}\text { K.E } \\
2 \text { (in } \\
\text { kJ) }\end{array}$ & $\begin{array}{c}\Delta \mathrm{K} . \mathrm{E} \\
= \\
\mathrm{K} . \mathrm{E}_{2}- \\
\mathrm{K} . \mathrm{E}_{1}\end{array}$ \\
\hline 0 & $\begin{array}{l}2.244(3 \\
3) \\
\end{array}$ & $\begin{array}{l}297.1 \\
5 \\
\end{array}$ & $\begin{array}{l}4.148(6 \\
1) \\
\end{array}$ & $\begin{array}{l}549.2 \\
7 \\
\end{array}$ & $\begin{array}{l}15.8 \\
0 \\
\end{array}$ & $\begin{array}{l}29.2 \\
1 \\
\end{array}$ & 13.41 \\
\hline 1 & 2.244 & $\begin{array}{l}297.1 \\
5 \\
\end{array}$ & $\begin{array}{l}4.012(5 \\
9)\end{array}$ & $\begin{array}{l}531.2 \\
6 \\
\end{array}$ & $\begin{array}{l}15.8 \\
0 \\
\end{array}$ & $\begin{array}{l}28.2 \\
5 \\
\end{array}$ & 12.45 \\
\hline 2 & 2.244 & $\begin{array}{l}297.1 \\
5 \\
\end{array}$ & $\begin{array}{l}3.876(5 \\
7) \\
\end{array}$ & $\begin{array}{l}513.2 \\
5 \\
\end{array}$ & $\begin{array}{l}15.8 \\
0 \\
\end{array}$ & $\begin{array}{l}27.2 \\
9 \\
\end{array}$ & 11.49 \\
\hline 3 & 2.244 & $\begin{array}{l}297.1 \\
5 \\
\end{array}$ & $\begin{array}{l}3.74(55 \\
)\end{array}$ & $\begin{array}{l}495.2 \\
5 \\
\end{array}$ & $\begin{array}{l}15.8 \\
0 \\
\end{array}$ & $\begin{array}{l}26.3 \\
4 \\
\end{array}$ & 10.54 \\
\hline 4 & 2.244 & $\begin{array}{l}297.1 \\
5 \\
\end{array}$ & $\begin{array}{l}3.604(5 \\
3)\end{array}$ & $\begin{array}{l}777.2 \\
4 \\
\end{array}$ & $\begin{array}{l}15.8 \\
0 \\
\end{array}$ & $\begin{array}{l}25.3 \\
8 \\
\end{array}$ & 9.58 \\
\hline
\end{tabular}

Table 9 Increase in kinetic energy at different age of tires ( maximum pressure $=61 \mathrm{psi}$ ) 


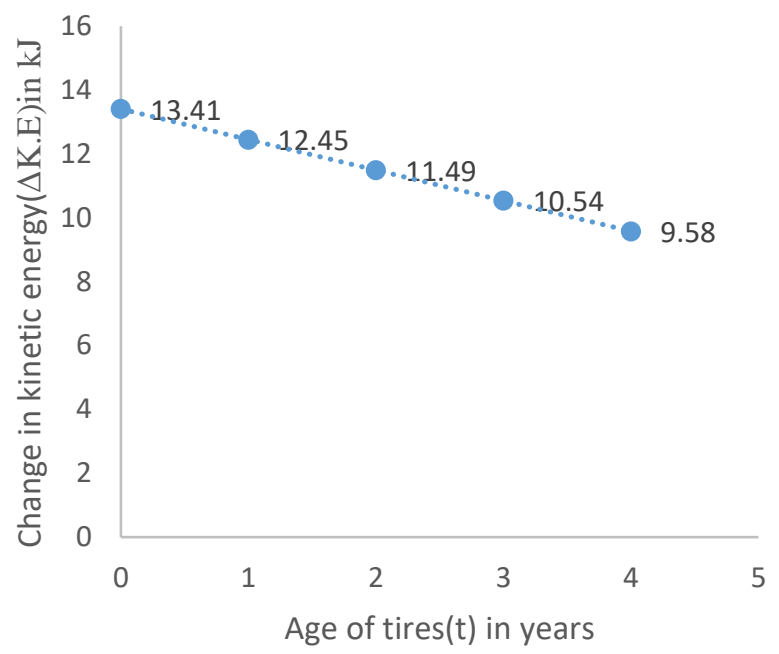

Fig. 12 Graph between age of tires and change in kinetic energy ( maximum pressure $=61 \mathrm{psi}$ )

Case VIII: when the normal pressure $=33 \mathrm{psi}$ and the maximum pressure of the tires $=60 \mathrm{psi}$

\begin{tabular}{|c|c|c|c|c|c|c|c|}
\hline $\begin{array}{l}\text { Age } \\
\text { of } \\
\text { tire, } t \\
\text { (in } \\
\text { years } \\
\text { ) }\end{array}$ & $\begin{array}{c}\mathrm{P}_{1} \\
\text { (in } \\
\mathrm{atm} \text { ) }\end{array}$ & $\begin{array}{c}\mathrm{T}_{1} \text { (in } \\
\mathrm{K} \text { ) }\end{array}$ & $\begin{array}{c}\mathrm{P}_{2} \text { ( in } \\
\mathrm{atm}) \text { (in } \\
\mathrm{psi} \text { ) }\end{array}$ & $\begin{array}{c}\mathrm{T}_{2} \text { (in } \\
\mathrm{K} \text { ) }\end{array}$ & $\begin{array}{l}\text { K. } E_{1} \\
\text { (in } \\
\text { kJ) }\end{array}$ & $\begin{array}{c}\text { K.E } \\
\text { (in } \\
\text { kJ) }\end{array}$ & $\begin{array}{c}\Delta \mathrm{K} . \mathrm{E} \\
= \\
\mathrm{K} . \mathrm{E}_{2}- \\
\mathrm{K} . \mathrm{E}_{1}\end{array}$ \\
\hline 0 & $\begin{array}{l}2.24 \\
4 \\
\end{array}$ & $\begin{array}{l}297.1 \\
5 \\
\end{array}$ & $4.08(60)$ & $\begin{array}{l}540.2 \\
7 \\
7\end{array}$ & $\begin{array}{l}15.8 \\
0\end{array}$ & $\begin{array}{l}28.7 \\
3\end{array}$ & 12.93 \\
\hline 1 & $\begin{array}{l}2.24 \\
4 \\
\end{array}$ & $\begin{array}{l}297.1 \\
5 \\
\end{array}$ & $\begin{array}{l}3.944(5 \\
8) \\
\end{array}$ & $\begin{array}{l}522.2 \\
6 \\
\end{array}$ & $\begin{array}{l}15.8 \\
0 \\
\end{array}$ & $\begin{array}{l}27.7 \\
7\end{array}$ & 11.97 \\
\hline 2 & $\begin{array}{l}2.24 \\
4 \\
\end{array}$ & $\begin{array}{l}297.1 \\
5 \\
\end{array}$ & $\begin{array}{l}3.808(5 \\
6)\end{array}$ & $\begin{array}{l}504.2 \\
5 \\
\end{array}$ & $\begin{array}{l}15.8 \\
0 \\
\end{array}$ & $\begin{array}{l}26.8 \\
1 \\
\end{array}$ & 11.01 \\
\hline 3 & $\begin{array}{l}2.24 \\
4 \\
\end{array}$ & $\begin{array}{l}297.1 \\
5 \\
\end{array}$ & $\begin{array}{l}3.672(5 \\
4)\end{array}$ & $\begin{array}{l}486.2 \\
4 \\
\end{array}$ & $\begin{array}{l}15.8 \\
0 \\
\end{array}$ & $\begin{array}{l}25.8 \\
6 \\
\end{array}$ & 10.06 \\
\hline 4 & $\begin{array}{l}2.24 \\
4 \\
\end{array}$ & $\begin{array}{l}297.1 \\
5 \\
\end{array}$ & $\begin{array}{l}3.536(5 \\
2)\end{array}$ & $\begin{array}{l}468.2 \\
3 \\
\end{array}$ & $\begin{array}{l}15.8 \\
0 \\
\end{array}$ & $\begin{array}{l}24.9 \\
0 \\
\end{array}$ & 9.10 \\
\hline
\end{tabular}

Table 10 Increase in kinetic energy at different age of tires ( maximum pressure $=60 \mathrm{psi}$ )

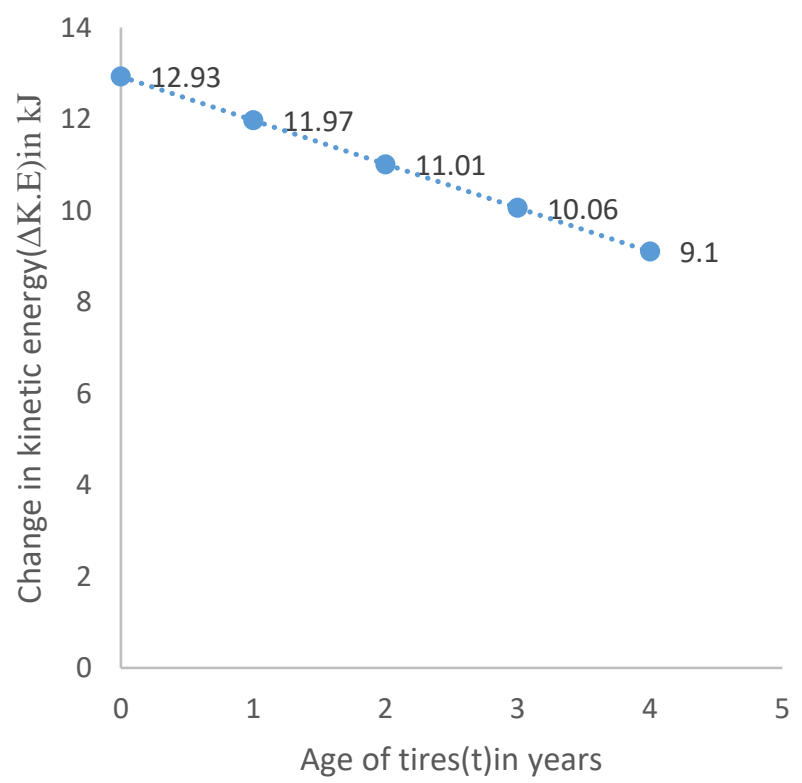

Fig. 13 Graph between age of tires and change in kinetic energy ( maximum pressure $=60 \mathrm{psi}$ )
Case IX: when the normal pressure $=33 \mathrm{psi}$ and the maximum pressure of the tires $=61 \mathrm{psi}$. And the rate of deterioration is not constant.

\begin{tabular}{|c|c|c|c|c|c|c|c|}
\hline $\begin{array}{l}\text { Age } \\
\text { of } \\
\text { tire, } t \\
\text { (in } \\
\text { years } \\
\text { ) }\end{array}$ & $\begin{array}{c}\mathrm{P}_{1} \\
\text { (in } \\
\mathrm{atm})\end{array}$ & $\begin{array}{c}\mathrm{T}_{1} \text { (in } \\
\mathrm{K} \text { ) }\end{array}$ & $\begin{array}{c}\mathrm{P}_{2} \text { (in } \\
\mathrm{atm})(\text { in } \\
\text { psi) }\end{array}$ & $\begin{array}{c}\mathrm{T}_{2} \text { (in } \\
\mathrm{K} \text { ) }\end{array}$ & $\begin{array}{c}\text { K.E } E_{1} \\
\text { (in } \\
\text { kJ) }\end{array}$ & $\begin{array}{l}\mathrm{K} . \mathrm{E}_{2} \\
\text { (in } \\
\mathrm{kJ} \text { ) }\end{array}$ & $\begin{array}{c}\Delta \mathrm{K} . \mathrm{E} \\
= \\
\mathrm{K}^{-\mathrm{E}_{2}} \\
\text { K.E }\end{array}$ \\
\hline 0 & $\begin{array}{l}2.24 \\
4\end{array}$ & $\begin{array}{l}297.1 \\
5\end{array}$ & $\begin{array}{l}4.148(6 \\
1)\end{array}$ & $\begin{array}{l}549.2 \\
7\end{array}$ & $\begin{array}{l}15.8 \\
0\end{array}$ & $\begin{array}{l}29.2 \\
1\end{array}$ & 13.41 \\
\hline 1 & $\begin{array}{l}2.24 \\
4\end{array}$ & $\begin{array}{l}297.1 \\
5\end{array}$ & $\begin{array}{l}4.012(5 \\
9)\end{array}$ & $\begin{array}{l}531.2 \\
6\end{array}$ & $\begin{array}{l}15.8 \\
0\end{array}$ & $\begin{array}{l}28.2 \\
5\end{array}$ & 12.45 \\
\hline 2 & $\begin{array}{l}2.24 \\
4\end{array}$ & $\begin{array}{l}297.1 \\
5\end{array}$ & $3.74(55)$ & $\begin{array}{l}495.2 \\
5\end{array}$ & $\begin{array}{l}15.8 \\
0\end{array}$ & $\begin{array}{l}26.3 \\
4\end{array}$ & 10.54 \\
\hline 3 & $\begin{array}{l}2.24 \\
4\end{array}$ & $\begin{array}{l}297.1 \\
5\end{array}$ & $\begin{array}{l}3.672(5 \\
4)\end{array}$ & $\begin{array}{l}486.2 \\
4\end{array}$ & $\begin{array}{l}15.8 \\
0\end{array}$ & $\begin{array}{l}25.8 \\
6\end{array}$ & 10.06 \\
\hline 4 & $\begin{array}{l}2.24 \\
4\end{array}$ & $\begin{array}{l}297.1 \\
5\end{array}$ & $\begin{array}{l}3.468(5 \\
1)\end{array}$ & $\begin{array}{l}459.2 \\
3\end{array}$ & $\begin{array}{l}15.8 \\
0\end{array}$ & $\begin{array}{l}24.4 \\
2\end{array}$ & 8.62 \\
\hline
\end{tabular}

Table 11 Increase in kinetic energy at different age of tires (maximum pressure $=61 \mathrm{psi}$ )

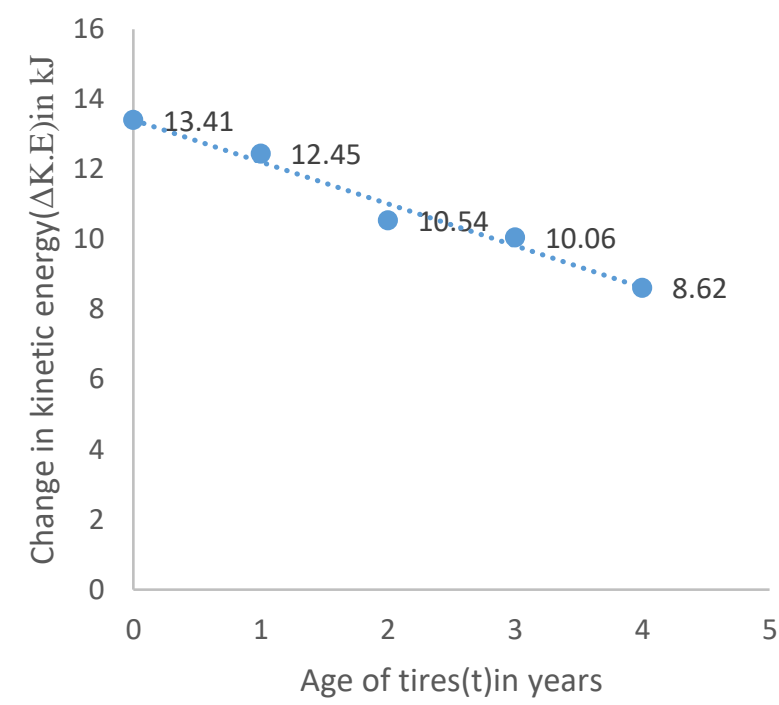

Fig. 14 Graph between age of tires and change in kinetic energy (maximum pressure $=61 \mathrm{psi}$ )

Case X: when the normal pressure $=40$ psi and the maximum pressure of the tires $=65 \mathrm{psi}$

\begin{tabular}{|c|c|c|c|c|c|c|c|}
\hline $\begin{array}{l}\text { Age } \\
\text { of } \\
\text { tire, } t \\
\text { (in } \\
\text { years } \\
\text { ) }\end{array}$ & $\begin{array}{c}\mathrm{P}_{1} \\
\text { (in } \\
\text { atm } \\
\text { ) }\end{array}$ & $\begin{array}{c}\mathrm{T}_{1} \text { (in } \\
\mathrm{K} \text { ) }\end{array}$ & $\begin{array}{l}\mathrm{P}_{2} \text { ( in } \\
\text { atm) (in } \\
\text { psi) }\end{array}$ & $\begin{array}{c}\mathrm{T}_{2} \text { (in } \\
\mathrm{K} \text { ) }\end{array}$ & $\begin{array}{c}\mathrm{K} . \mathrm{E}_{1} \\
\text { (in } \\
\mathrm{kJ} \text { ) }\end{array}$ & $\begin{array}{l}\mathrm{K} . \mathrm{E}_{2} \\
\text { (in } \\
\mathrm{kJ} \text { ) }\end{array}$ & $\begin{array}{c}\Delta \mathrm{K} . \mathrm{E} \\
= \\
\mathrm{K}^{-\mathrm{E}_{2}} \\
\text { K. } \mathrm{E}_{1}\end{array}$ \\
\hline 0 & $\begin{array}{l}2.7 \\
2 \\
\end{array}$ & $\begin{array}{l}297.1 \\
5 \\
\end{array}$ & $4.42(65)$ & $\begin{array}{l}482.8 \\
6 \\
\end{array}$ & $\begin{array}{l}15.8 \\
0 \\
\end{array}$ & $\begin{array}{l}25.6 \\
8 \\
\end{array}$ & 9.88 \\
\hline 1 & $\begin{array}{l}2.7 \\
2 \\
\end{array}$ & $\begin{array}{l}297.1 \\
5 \\
\end{array}$ & $\begin{array}{l}4.284(6 \\
3) \\
\end{array}$ & $\begin{array}{l}468.0 \\
1 \\
\end{array}$ & $\begin{array}{l}15.8 \\
0 \\
\end{array}$ & $\begin{array}{l}24.8 \\
9 \\
\end{array}$ & 9.09 \\
\hline 2 & $\begin{array}{l}2.7 \\
2 \\
\end{array}$ & $\begin{array}{l}297.1 \\
5 \\
\end{array}$ & $\begin{array}{l}4.148(6 \\
1)\end{array}$ & $\begin{array}{l}453.1 \\
5 \\
\end{array}$ & $\begin{array}{l}15.8 \\
0 \\
\end{array}$ & $\begin{array}{l}24.1 \\
0 \\
\end{array}$ & 8.30 \\
\hline 3 & $\begin{array}{l}2.7 \\
2 \\
\end{array}$ & $\begin{array}{l}297.1 \\
5 \\
\end{array}$ & $\begin{array}{l}4.012(5 \\
9)\end{array}$ & $\begin{array}{l}438.2 \\
9\end{array}$ & $\begin{array}{l}15.8 \\
0\end{array}$ & $\begin{array}{l}23.3 \\
1 \\
\end{array}$ & 7.51 \\
\hline 4 & $\begin{array}{l}2.7 \\
2 \\
\end{array}$ & $\begin{array}{l}297.1 \\
5\end{array}$ & $\begin{array}{l}3.876(5 \\
7)\end{array}$ & $\begin{array}{l}423.4 \\
3\end{array}$ & $\begin{array}{l}15.8 \\
0\end{array}$ & $\begin{array}{l}22.5 \\
2\end{array}$ & 6.72 \\
\hline
\end{tabular}

Table 12 Increase in kinetic energy at different age of tires ( maximum pressure $=65 \mathrm{psi}$ ) 


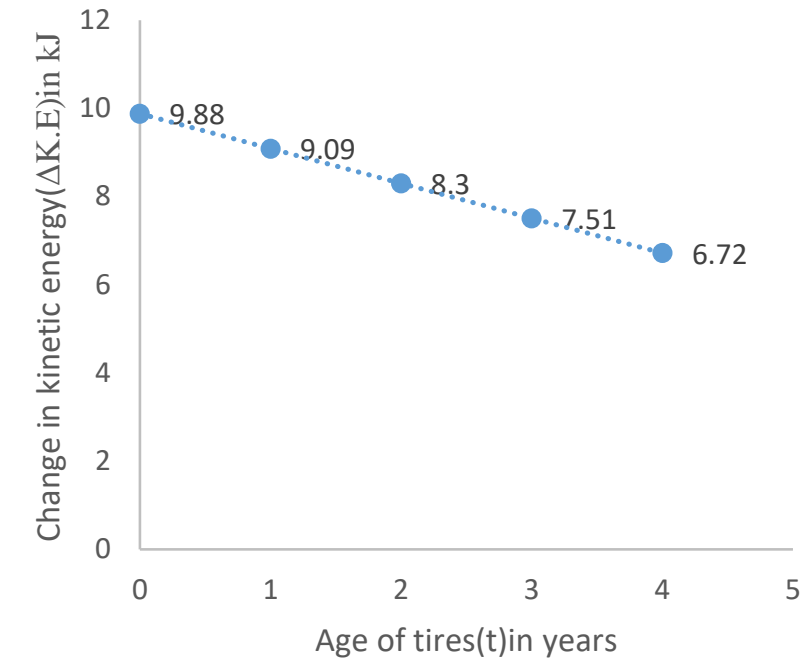

Fig. 15 Graph between age of tires and change in kinetic energy ( maximum pressure $=65 \mathrm{psi}$ )

Case XI: when the normal pressure $=40$ psi and the maximum pressure of the tires $=66 \mathrm{psi}$

\begin{tabular}{|c|c|c|c|c|c|c|c|}
\hline $\begin{array}{l}\text { Age } \\
\text { of } \\
\text { tire, } t \\
\text { (in } \\
\text { years } \\
\text { ) }\end{array}$ & $\begin{array}{l}\mathrm{P}_{1} \\
\text { (in } \\
\text { atm } \\
\text { ) }\end{array}$ & $\begin{array}{c}\mathrm{T}_{1} \text { (in } \\
\mathrm{K})\end{array}$ & $\begin{array}{c}\mathrm{P}_{2} \text { ( in } \\
\text { atm) (in } \\
\text { psi) }\end{array}$ & $\begin{array}{c}\mathrm{T}_{2} \text { (in } \\
\mathrm{K} \text { ) }\end{array}$ & $\begin{array}{c}\text { K.E } \\
\text { (in } \\
\text { kJ) }\end{array}$ & $\begin{array}{l}\mathrm{K}^{\mathrm{K} \mathrm{E}_{2}} \\
\text { (in } \\
\mathrm{kJ} \text { ) }\end{array}$ & $\begin{array}{c}\Delta \mathrm{K} . \mathrm{E} \\
= \\
\mathrm{K} . \mathrm{E}_{2-} \\
\mathrm{K} . \mathrm{E}_{1}\end{array}$ \\
\hline 0 & $\begin{array}{l}2.7 \\
2\end{array}$ & $\begin{array}{l}297.1 \\
5\end{array}$ & $\begin{array}{l}4.488(6 \\
6)\end{array}$ & $\begin{array}{l}490.2 \\
9\end{array}$ & $\begin{array}{l}15.8 \\
0\end{array}$ & $\begin{array}{l}26.0 \\
7\end{array}$ & 10.27 \\
\hline 1 & $\begin{array}{l}2.7 \\
2\end{array}$ & $\begin{array}{l}297.1 \\
5\end{array}$ & $\begin{array}{l}4.352(6 \\
4)\end{array}$ & $\begin{array}{l}475.4 \\
4\end{array}$ & $\begin{array}{l}15.8 \\
0\end{array}$ & $\begin{array}{l}25.2 \\
8\end{array}$ & 9.48 \\
\hline 2 & $\begin{array}{l}2.7 \\
2\end{array}$ & $\begin{array}{l}297.1 \\
5\end{array}$ & $\begin{array}{l}4.216(6 \\
2)\end{array}$ & $\begin{array}{l}460.5 \\
8\end{array}$ & $\begin{array}{l}15.8 \\
0\end{array}$ & $\begin{array}{l}24.4 \\
9\end{array}$ & 8.69 \\
\hline 3 & $\begin{array}{l}2.7 \\
2\end{array}$ & $\begin{array}{l}297.1 \\
5\end{array}$ & $4.08(60)$ & $\begin{array}{l}445.7 \\
2\end{array}$ & $\begin{array}{l}15.8 \\
0\end{array}$ & $\begin{array}{l}23.7 \\
0\end{array}$ & 7.90 \\
\hline 4 & $\begin{array}{l}2.7 \\
2\end{array}$ & $\begin{array}{l}297.1 \\
5\end{array}$ & $\begin{array}{l}3.944(5 \\
8)\end{array}$ & $\begin{array}{l}430.8 \\
6\end{array}$ & $\begin{array}{l}15.8 \\
0\end{array}$ & $\begin{array}{l}22.9 \\
1\end{array}$ & 7.11 \\
\hline
\end{tabular}

Table 13 Increase in kinetic energy at different age of tires ( maximum pressure $=66 \mathrm{psi}$ )

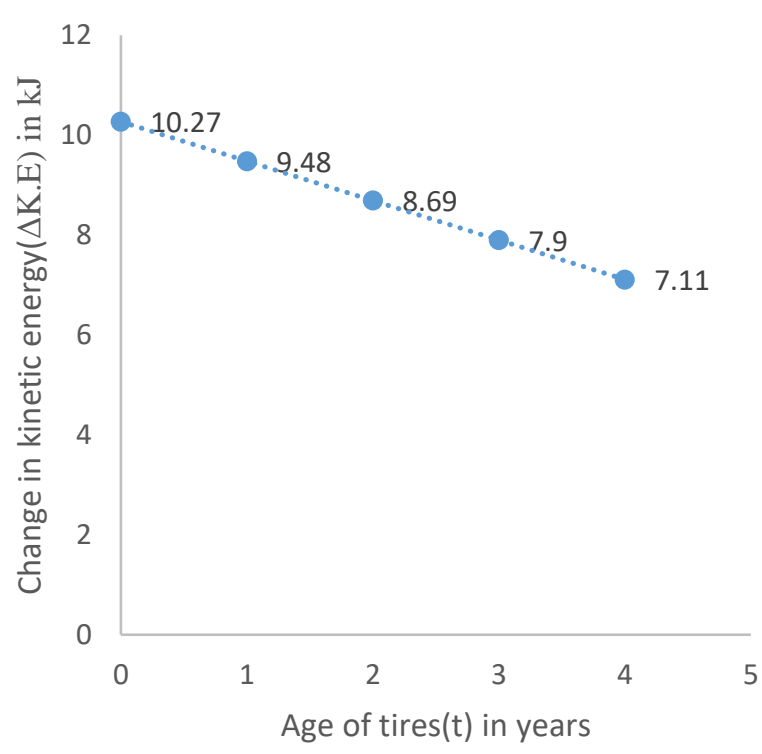

Fig. 16 Graph between age of tires and change in kinetic energy ( maximum pressure $=66 \mathrm{psi}$ )
From the above analysis of different cases of nominal and maximum pressure of different tires we can obtain a range of texture depths that can be constructed on the pavement considering the worst case involved in the tires.

We take the weight of the un-laden vehicle $=870 \mathrm{~kg}$

Weight on single wheel (considering equal distribution of weight on four wheels) $=870 / 4=217.5 \mathrm{~kg}$

As we know that force $*$ displacement $=$ work done

The texture depths are considered as a vertical distance and as soon as the rubber tires rolls over it tends to deflect a small distance $\mathrm{x}$, because of its weight so for different deflection different energies for different depth of deflection can be obtained and has been tabulated below.

\begin{tabular}{|l|l|}
\hline Texture Depth in mm & Work done in J \\
\hline 2.0 & 0.435 \\
\hline 2.2 & 0.478 \\
\hline 2.5 & 0.543 \\
\hline 2.75 & 0.598 \\
\hline 2.8 & 0.609 \\
\hline 3.0 & 0.652 \\
\hline 3.5 & 0.761 \\
\hline 3.75 & 0.815 \\
\hline 4.0 & 0.875 \\
\hline
\end{tabular}

Table 14 Work done by single different texture depths

Taking average life of tires as 3 years and considering that the increase in kinetic energy is $1 \%$ because of friction and rest by the texture depth we get that for tire with $28 \mathrm{psi}$ nominal pressure $10.16 \mathrm{~kJ}$ as minimum energy to reach to the case of maximum holding pressure, for $30 \mathrm{psi} 5.27 \mathrm{~kJ}$, for 33 psi $11.01 \mathrm{~kJ}$ and for $40 \mathrm{psi} 8.30 \mathrm{~kJ}$. But since all these calculations are the cases involving the optimum conditions which is not the case in the present situation. The texture depth of about $<1.8 \mathrm{~mm}$ is optimum for every situation but the test site involved had more depth so considering the basic number of texture depth as 150 we can give the conclusion of having optimum texture depth that is required for this pavement.

Going by the same methods of analysis for different texture depths starting from $4.0 \mathrm{~mm}$ we get the following calculations for different depths:

For $4.0 \mathrm{~mm}$ depth: taking number of texture depths as 150 per $\mathrm{km}$ of the pavement, we get the energy contributed by all texture depth for $1 \mathrm{~km}$ as $=150 * 0.87 \mathrm{~J}$

Similarly for $150 \mathrm{~km}$ length $=150 * 150 * 087=19.575 \mathrm{~kJ}$

Since the tire had initial energy $=15.80 \mathrm{~kJ}$ for $24^{\circ} \mathrm{C}$

Therefore the total energy attributed by texture will be 15.80 $+19.575=35.37 \mathrm{~kJ}$

$35.37 * 1000=20.5 * 1.38 * 2.56 * 6.022 * \mathrm{~T}$

$\mathrm{T}=665.02 \mathrm{~K}$

From Gay -Lussac's law,

$$
\frac{P_{1}}{T_{1}}=\frac{P_{2}}{T_{2}}
$$

For $\mathrm{P}_{1}=30$ psi $\mathrm{T}_{1}=297.15 \mathrm{~K}, \mathrm{~T}_{2}=665.02 \mathrm{~K}$

We get $\mathrm{P}_{2}=67 \mathrm{psi}$

Similarly for other depths $3.75 \mathrm{~mm}, 3.5 \mathrm{~mm}, 3.0 \mathrm{~mm}, 2.8$ $\mathrm{mm}, 2.75 \mathrm{~mm}, 2.5 \mathrm{~mm}, 2.2 \mathrm{~mm}$ different values of final pressure has been calculated and tabulated below: 
Texture Depth (in mm)

\begin{tabular}{|c|c|}
\hline Texture Depth (in mm) & Final pressure $\mathbf{P}_{\mathbf{2}}$ (in psi) \\
\hline 4.0 & 67 \\
\hline 3.75 & 65 \\
\hline 3.5 & 62 \\
\hline 3.0 & 58 \\
\hline 2.8 & 56 \\
\hline 2.75 & 54 \\
\hline 2.5 & 53 \\
\hline 2.2 & 50 \\
\hline
\end{tabular}

Table 15 Maximum pressure build up for different texture depths

\section{CONCLUSION}

- When the external force does not passes through the centre of mass of the body then it produces angular acceleration along with the linear acceleration resulting in the increase in angular velocity of the body. This process makes the body to slide in the backward direction and here comes the friction which acts in the direction of the force to produce anticlockwise torque to counter act the sliding process hence in helping the body to rotate without sliding with acceleration. It is seen from the concept of rolling that work done by friction is zero and hence here in our study it is concluded that the work done by friction between the rubber tire and the pavement surface is not completely zero but is very small in contributing the energy inside the tire to the gas filled with respect to other sources of energy. We here conclude that the major dissipation of energy in the form of heat is done to the surroundings and less inside the tire since the materials of the tire with high cross link density decreases the conductivity of the tread material as mentioned in the study done in 2006 and it helps the tires to sustain a high temperature in the critical points.

- Whereas in the rigid pavement there are slabs made of concrete either reinforced or without reinforcement, so firstly there are formation of many stresses due to the various climatic factors and changes accordingly too. The friction in these pavements is provided by the formation of textures on its surface. It is seen that due to the repetition of loads these textures tends to get polished and the friction value decreases which not only increases the sliding phenomenon in the rolling tire but also increases the dissipation of energy in the form of heat which causes the wearing of the tire. In the older tires or tires with low inflation pressure tends to get burst as they are not able sustain such high amount of energy.

- This was one aspect where textures play a role in the wearing of the tires. The second aspect of it is if the textures width is increased about $>500 \mathrm{~mm}$, the tires will take a point contact with two ends of the texture wavelength and will experience much high pressure due to less area of contact. It will give better friction but due to continuous direct impact the tires will experience tremendous high stresses and hence will increase the kinetic energy of the enclosed gas molecules. The cross ply tires won't be able to bear such high energy due less flexibility of the sidewall and hence will burn out whereas in radial tires this will be limited to a certain value and limit due to the flexible nature of the sidewalls of the radial tires.

- We can make a conclusion about the pavement test site that considering the final age of the tires to be 3 years, in this pavement texture depth $>3.5 \mathrm{~mm}$ will lead to the bursting of the tires if it satisfies every condition of it so for safety of most vehicle tires depth $<2.5-2.8 \mathrm{~mm}$ can be considered the ideal texture depth. More than this can lead to the frequent degradation of the newer tires and bursting of the old tires if not properly handled leading to major accidents.

\section{FUTURE SCOPE}

Based on the present work and findings it is believed that better analysis can be done with more advanced technical structure and a relation could be formed though all the proper care that was required was taken.

- The relation between the texture on the pavement and the speed of the vehicle could be formed with better data collection and analysis.

- The exact percentage of the contribution of the friction in the increase in the kinetic energy could not be calculated and requires further analysis.

- There were more ideal assumptions that were used to calculate the amount of energy inside the rolling tire which can alter with the conditions in the real world.

- A deeper study can be adopted for the calculation of energy attributed by the texture as this whole process of analysis is a complex phenomenon.

\section{REFERENCES}

[1] Ahammed A Mohammad, Tighe Susan (2008) "Pavement Surface Mixture, Texture and Skid Resistance: A Factorial Analysis" ASCE Library by University of Water Loo.

[2] Alan Dunford (2013), "Friction and the texture of Aggregate particles used in the Surface course”, wear 292, 188-196.

[3] Beer De Morris, Maina James, Greben Jan "Toward using tire road contact stresses in pavement design and analysis" Tire Science and Technology, TSTCA Vol. 4, No.4, pp 246-271.

[4] Chemistry Libre Texts; chem.libretexts.org $>2.6$ Kinetic theory of gases- Chemistry LibreTexts.

[5] Er. R.K Rajput, "Heat and Mass Transfer”, S .Chand Publications; Fifth revised edition 2012.

[6] Huang Xi Meng, Li Ziran, Yuanming Xia (2012) "The Interior Temperature Distribution Measurement in a Rolling Tire" proceedings of 2012 International Conference on Mechanical Engineering and Material Science.

[7] Lin Yeong-Jyh and Hwang Sheng-Jye (2004), "Temperature prediction of rolling tires by computer simulation", Math. Comp. Simul, 67, 235-249 (2004)

[8] P. S. Grinchuk and S. P. Fisenko (2016), "Rate of dissipation of low-frequency mechanical disturbances in a tire", J. Eng. Thermo physics, 89, No. 6, 1365-1368 (2016).

[9] R. Behnke and M. Kaliske (2015), "Thermo-mechanically coupled investigation of steady state rolling tires by numerical simulation and experiment" , International Journal of Non Linear Mechanics,68.101-1312015.

[10] Sassi Sadok, Sassi Abdelmonem (2015) "Destabilising effect of tyre burst on vehicle's dynamics" International Journal of Vehicle Systems Testing and Modelling Vol. 10,No 2 DOI 10.1504.

[11] S.K Khanna, C.Eg. Justo and A. Veeraragavan, "Highway Engineering"; Nem Chand \& Bros, Roorkee, Revised $10^{\text {th }}$ edition. 
[12] Tabrizi Basirat H, Afzali B (2006) "Effect of Nonstandard Curing Conditions on Thermal properties and Temperature Distribution of a Rolling Tire" presented at Meeting of the Tire Society.

[13] Woodward David, Woodside R Alan (2011) "Road contact stresses and forces under tires with low inflation pressure" Article in Canadian Journal of Civil Engineering DOI 10.1139.

[14] Zuraulis Vidas, Levulyte Loreta,Sokolovskij Edgar (2014) "The Impact of Road Roughness on the duration of contact between a vehicle and Road surface" article in TRANSPORT DOI $10.3846 / 16484142$. 